\title{
Behavioral Changes among Street Level Drug Trafficking Organizations and the Fluctuation in Drug Prices Before and During the Covid-19 Pandemic
}

\author{
Umit Namli ${ }^{1}$ \\ University of Tubingen, Germany
}

\begin{abstract}
This article focused on behavioral changes in street-level drug trafficking organizations and drug price fluctuations at the retail level during the COVID-19 in Germany, specifically in North RhineWestphalia. This study's primary purpose was to understand how the pandemic affected low-level drug markets and whether precautions taken to prevent the spread of disease caused any changes in their operations. Moreover, drug prices were compared before and during the Corona-19 pandemic. This study used a narrative analysis. Thirteen participants, some of whom used multiple drugs and all of whom are regular users, were interviewed from March 2020 to September 2020. Study results showed no significant change either in open or closed markets except for curfew times. Moreover, no shortages existed in the drug supply chain. Nevertheless, there were slight changes in drug distribution methods. Furthermore, contrary to the assumptions, the demand for using the Internet drug market did not increase during the pandemic.
\end{abstract}

KEYWORDS: Coronavirus, Pandemic, COVID-19, Closed Drug Market, Darknet, Drug Distributions, Drug Prices, Open Drug Market, Street-level Drug Trafficking, Germany.

The COVID-19 pandemic has a profound effect on social and economic life throughout the world (Ojha, 2020). Since the pandemic first had appeared at the beginning of 2020, more than 68 million people have been infected more than 1,5 million people had lost their lives as of December 2020, according to the World Health Organization. Governments in different countries took intensive measures to combat the disease's spread by shuttering educational institutions, restaurants, and public domains where the population was gathered in close proximity (Aliyyah et al., 2020; Garbe et al., 2020). Borders were closed, flights were canceled, and travel restrictions were implemented strictly, and some countries declared a curfew to prevent the spread of the disease. Millions of people were home imprisoned for months because of lockdowns.

Following the pandemic outburst, politicians, academicians, and law enforcement agencies tried to understand the potential effects of the COVID-19 on crime and criminal activities and what type of policies or responses should be developed to prevent illegal activities under the new circumstances. The first studies showed that damage against the property such as robbery, thefts, and shoplifting decreased compared to the times before the COVID-19 in Los Angeles, which was probably related to the social distance precautions, less visibility in commercial areas, and the increased supervision over belongings (Campedelli et al., 2020; Mohler et al., 2020). However, no significant change seemed to occur in crimes against people, such as homicide and assault

\footnotetext{
${ }^{1}$ Corresponding Author E-mail: uemit.namli@jurfak.uni-tuebingen.de
} 
(Campedelli et al., 2020), although an increase in domestic violence might have transpired (Bullinger et al., 2020; Campedelli et al., 2020; Mohler et al., 2020) because of the stressful environment resulted from economic concerns and being quarantined in a closed environment (Campedelli et al., 2020).

In the meantime, some organized crime groups also changed their focus and penetrated the healthcare system via medical supplements, threatening health systems and public health (Eligh, 2020). Furthermore, organized crime groups also used the current situation to gain sympathy from the public to enlarge their networks and find new members by appearing on the streets to enforce curfews and control their territories to provide social distance (Eligh, 2020; Sullivan et al., 2020). They also provided aid packs to support families who could not go out due to lockdowns. During their activities, they blamed local politicians for not supporting aggrieved families (Eligh, 2020). Due to financial constrictions, governments could not provide enough support for local businesses in some countries. Thus, local criminal groups delivered financial support to those local businesses with high-interest rates, all of which threatened the state sovereign, social and economic structure of the legitimate governments (Sullivan et al., 2020).

Because of travel restrictions, drug trafficking was expected to decrease. However, even though social and economic life shrunk dramatically worldwide, a similar trend could not be observed in transnational organized crime groups, especially transnational drug trafficking organizations. On the contrary, according to UNODC reports, law enforcement agencies seized more illegal substances compared to the previous years in the same period (European Monitoring Centre for Drugs and Drug Addiction and Europol, 2020).

Drug users are much more prone and vulnerable to disease than non-drug users because of their specific drug consumption behaviors, such as needle exchange or other instruments used during drug consumption. Furthermore, both the COVID-19 virus and illegal drugs cause respiratory problems and profoundly affect the immune system (Eligh, 2020; EMCDDA, 2019; European Monitoring Centre for Drugs and Drug Addiction, 2020). However, a recent report showed that there seemed to be neither reduction in street-level supply nor demand reduction. Moreover, there seems to be no increase in the street prices of drugs. Even though there were some fluctuations at the beginning of the disease's spread because of the social distance measures (Sikhangezile \& Modise, 2020), in a short period, drug markets relaxed and reached the same level as before the COVID-19 (European Monitoring Centre for Drugs and Drug Addiction and Europol, 2020).

\section{Purpose of the Study and Research Questions}

Even now, eleven months after the first COVID-19 case was seen globally, few studies have measured how pandemic affected illegal drug markets in Germany. In this regard, this study's results will help Law enforcement agencies and policymakers understand the situation in two ways. The first is how preventive measures like travel restrictions and curfews helped to curb drug distribution on the street and drug use even though those precautions were not explicitly taken to prevent drug consumption. The second is what other policies or strategies should be developed in such a pandemic situation and in any other circumstances when extraordinary precautions were taken to minimize drug distribution and consumption.

Therefore, as a first step, this study will examine if there were any changes in drug prices and drug distribution methods by comparing the situation before and during COVID-19 and give a short brief description of similar crisis eras and other times of shortage. In this context, the following two questions are examined: 
1) Were there any differences in drug distribution methods before and during the COVID-19 pandemic?

2) How did COVID-19 affect drug prices on the street level?

\section{Literature Review}

\section{Previous Crises and Market Response}

The current pandemic is not the first and, probably, not the last extraordinary situation affecting social and economic life and drug markets globally. Indeed, different circumstances have typically affected the prices and distribution methods of drugs in the streets, some of which are law enforcement intervention and unforeseen external factors such as a pandemic, precursor shortages, etc. (Caulkins, 2007; Eligh, 2020).

Historically, in the last fifty years, drug markets faced several shortages and crises; however, none of those crises was as severe or prevalent as the current one due to the precautions taken against the spread of the pandemic. Furthermore, law enforcement agencies have conducted successful operations to intervene in drug supply chains during the pandemic.

The first crisis burst out in the middle of 1990 when the American government enacted the US Domestic Chemical Diversion Control Act to restrict access to certain chemicals that synthetic drug producers used (Dobkin \& Nicosia, 2009; Eligh, 2020; Sacco, 2015). The American Drug Enforcement Agency canceled the licenses of the two leading chemical companies, which provided almost $50 \%$ of the American demand for these chemicals. The supply network for the chemicals used in the production of synthetic drugs was disrupted, and drug markets in the United States fluctuated, which caused synthetic drug shortages in the country (Dobkin \& Nicosia, 2009; Eligh, 2020). Drug trafficking organizations responded to this situation (Dobkin \& Nicosia, 2009; Eligh, 2020) by tripling methamphetamine prices and decreasing drug purity by almost $70 \%$ decreased (Dobkin \& Nicosia, 2009; Eligh, 2020).

The second shortage occurred in 2000 and 2001 when the Taliban regime disrupted poppy fields in Afghanistan. After poppy cultivation was declared "haram" (forbidden) in the Afghanistan, poppy cultivation decreased by $90 \%$, and opium gum production decreased by $96 \%$ (Demirbüken et al., 2009; Eligh, 2020; United Nations Office on Drugs and Crime, 2008).

The third drug market crisis occurred in 2003 with the spread of SARS acute syndrome. Even though it did not affect the entire world drug market like COVID-19, the 2003 crisis severely affected some parts of China and Hong Kong. Limited studies showed that drug consumption during the same period had decreased until the crisis was over and then raised to the same level before the crises (Eligh, 2020).

The fourth crisis was observed in the 2008 economic depression. The outcome of the crises showed mixed results in different countries. For example, while cocaine and cannabis consumption was increasing in Spain, they decreased in the rest of the European countries and Ireland (Eligh, 2020). Again while the consumption of relatively expensive drugs such as cocaine and heroin decreased, the consumption of cannabis and synthetic drugs increased in Italy (Zuccato et al., 2011).

Another heroin shortage was observed in 2010 and 2011 because of the fungus epidemic in opium farms in Afghanistan, which resulted in an effect similar to that of the 2000 crisis (Demirbüken et al., 2009; Eligh, 2020). The prices of heroin and its derivate increased, and drug purity decreased. To get the best effect from heroin, injection practices increased, which boosted the possibility of diseases spread with injection. Another substantial effect was experienced the year after the crisis was over because of overdose deaths. 
Even though the above-mentioned crises affected drug markets and distribution chains, drug traffickers adapt themselves to new circumstances by implementing new marketing and distribution strategies in each of those crises. Nevertheless, many dealers disappeared from the market during these shortages while some took a vacation, got a new number and telephone, or moved to another city. Some described the situation to their customers and asked for patience; some referred their customers to other dealers (Tzvetkova et al., 2016).

In this context, COVID-19 resulted in both advantages and disadvantages for drug trafficking organizations. While the current circumstances negatively affected distribution networks, drug trafficking organizations found alternative methods and channels to distribute their illegal products (Eligh, 2020).

\section{Drug Distribution in the Market and Drug Prices}

\section{Drug Market Types and Their Characteristics}

Similar to legitimized commercial activities, drug trafficking transactions are carried out among those who locate each other in the illegal drug markets (Haracopos \& Hough, 2005; May \& Hough, 2004); however, illegal drug markets differ from the legitimate businesses in some aspects, such being open to law enforcement intervention, and the high possibility of being ripped off. Moreover, no legitimate authority exists if a conflict of interest arises between the parties (Reuter \& Caulkins, 2004).

Depending on the risk and gain preference that is the nature of the business, drug retailers' behavior shapes the drug markets based on where and how they would like to operate, either open or closed drug markets (Haracopos \& Hough, 2005; May \& Hough, 2004). Nevertheless, the following four criteria have a determining effect on the selection of the illegal drug markets. First are in those regions where economic deprivation more distinct/observed. Second are specific geographical areas where customers know where they can reach dealers. Third are transportation hubs, which help distribution due to easy access. Fourth are the places that users habituation because particular heavy drug addicts like heroin and crack cocaine users require constant service (Haracopos \& Hough, 2005).

Characteristics of the drug markets also vary according to the type of substance sold in the markets (Haracopos \& Hough, 2005). Studies have shown most dealers sell multiple types of drugs, and cannabis is the most sold drug on the streets (Bucerius, 2007; Sandberg, 2012). Nevertheless, dealers adjust the type of drugs on the street according to exiting circumstances. For example, when police focus on cocaine sellers, dealers change their merchandise products to remain under the radar of the law enforcement agencies or avoid police investigations (Bucerius, 2007).

Even though it is assumed that drug dealers are the only source for users, this assumption seems to be a myth. Studies have shown that the most reliable source for users is friends rather than dealers (Decorte, 2001; Sandberg, 2012). For example, Decorte (2001) found that almost $40 \%$ of the cocaine users received cocaine from their friends, 35\% bought the drug from regular dealers, and slightly more than $20 \%$ of users bought the drug from random dealers. This finding shows that almost 3 of 4 users obtained drugs from their closed circles rather than open markets.

Drug markets are traditionally separated into open and closed markets. Nevertheless, in recent years, online drug markets, commonly known as the Darknet, have become more popular among dealers and users. 


\section{Open Markets}

Open drug market refers to the illegal drug market, which is open to any buyer who desires to use illegal drugs without a proper introduction to the seller or vice versa. Open markets provide certain advantages such as selling or buying various quality products, gaining more profit and reaching more customers. Drug dealers operate in specific geographical locations and in certain periods (Haracopos \& Hough, 2005; May \& Hough, 2004).

In open markets, drug dealers conduct their business in crowded places such as train or bus stations or in busy streets, which provide them excellent cover to hide among the crowds (May \& Hough, 2004). Besides strategic geographical situations, environmental conditions also affect an open market. These include the presence of street lights, places where visibility decreases due to wooded or bushland areas, the structure of the streets, vacant buildings, and parking spaces (Haracopos \& Hough, 2005). Nevertheless, dealers still should be visible or noticeable to potential customers with their clothes or attitudes (Coomber \& Maher, 2006).

However, visibility is not all-encompassing for dealing with all the potential buyers. Dealers like to know or see if a buyer has enough street sense and knows drug jargon. In the case of inadequate response from the potential buyer, a dealer simply walks away from the business due to a fear of police intervention (Coomber \& Maher, 2006). Therefore, this unique situation creates a burden on a customer to prove that he/she is safe enough to conduct business with (Coomber \& Maher, 2006).

The general profile of the open drug market distributors differs from the middle and highlevel dealers. Street-level dealers are at the bottom of the trafficking organizations and not necessarily related to a specific organization (Bucerius, 2007; Haracopos \& Hough, 2005). They might be engaging with drug selling to provide for their habit, and they are generally socially isolated and unemployed (Haracopos \& Hough, 2005). Therefore, it is unnecessary to work with one of the drug trafficking organizations in the open drug market. Such a dealer be self-employed and might be working as a freelancer seller. Previous studies have shown that almost half of the dealers who operate in some promising regions are self-employed dealers regardless of the drug they sell, including heroin. Nevertheless, they might team up with other sellers who work with bigger organizations (Coomber \& Maher, 2006). The share of the money gained from the drug business is also distributed differently according to the dealers' position. While self-employed dealers keep all the profits themselves, those who work for a boss receive either a fixed amount of money or a percentage from the sales (Coomber \& Maher, 2006).

However, despite all the advantages, open market dealers are more vulnerable than other markets to law enforcement intervention, fraudulence, bullying, robbery, and lack of compensation if the drug does not meet expectations (Haracopos \& Hough, 2005; May \& Hough, 2004). Studies have shown that while only $30 \%$ of drug users buy drugs from non-reliable dealers, more than $70 \%$ of users were ripped off at least once in their life by getting either nothing, less than the amount than expected, or a substance different than they were supposed to have (Decorte, 2001).

Often police intervention in the open drug market has either a limited or no effect on the market or consumption rates in the drug market because others replace an arrested dealer. Indeed, other dealers become happier because their revenue increases and law enforcement agencies terminate their rivals (Haracopos \& Hough, 2005).

\section{Closed Markets}

Contrary to open markets, closed drug market sales are conducted among those who know each other, and contacts are made only through personal references (Bucerius, 2007; Haracopos \& 
Hough, 2005; May \& Hough, 2004). The expansion of the closed market is related to the law enforcement threat level, as a closed market expands when the threat level is high. Because of security concerns, any open markets can be transferred to the closed market, conducting business in the closed markets the most desired markets for dealers and buyers (May \& Hough, 2004). Studies have shown that drug users would prefer to conduct their business with a dealer they know is reliable in provides good quality, has reasonable prices, and the actual amount of the drug stated in the deal (Decorte, 2001).

Besides security issues, closed markets provide an excellent opportunity for buyers and sellers to locate each other (May \& Hough, 2004). They can contact each other by mobile phones, which is considered a safe communication method between dealer and seller; moreover, cell phones and lines can be quickly and regularly changed (May \& Hough, 2004). This business model also decreases the possibility of law enforcement intervention, fraudulence, and robbery (Haracopos \& Hough, 2005; May \& Hough, 2004).

Nevertheless, closed markets also have disadvantages for dealers, such as limited marketing opportunities and limitations in increasing the product's price to the new customers because they work with only those who know or are referred to them.

\section{Internet Sales}

Due to complicated and encrypted data exchange methods through special web browsers, such as Tor, the Darknet became one of the most preferred markets for illicit activities (Weber \& Kruisbergen, 2019). Even though Darknet has been in use since 2010, it drew the attention of both customers and sellers, specifically after the Silk Road platform, which was established in 2011. Nevertheless, Silk Road is not the only platform to sell and buy illegal products, including illegal drugs, weapons, stolen identities, and other unlawful goods through the Internet. More than 100 other similar platforms serve the same purposes (Byrne \& Martinez, 2012; Europol, 2017; United Nations Office on Drugs and Crime, 2018; Weber \& Kruisbergen, 2019). However, drug transactions are the most common illegal activity; in fact, six of every ten advertisements are related to illicit drug sales (Europol, 2017; United Nations Office on Drugs and Crime, 2018).

According to EMCCDA and Europol, cocaine and heroin are the most listed illicit drugs globally, while amphetamine-type stimulants and other synthetic drugs, including sedatives, take their place in the sales list (Europol, 2017; United Nations Office on Drugs and Crime, 2018). Europol's (2017) report also indicated that between 2011 and 2015, Germany, Netherland, and the UK are the biggest drug supplier in the market among the European countries (Weber \& Kruisbergen, 2019).

Darknet online platform also provided such opportunities for both buyers and vendors through the feedbacks which was left by previous customers. Thus, the main concerns such as receiving the uncertain quality of drug minimized by conducting business with the verified vendors and paying for the merchandise is guaranteed until the delivery is carried out (United Nations Office on Drugs and Crime, 2018).

All these features increase the popularity of online drug transactions. For example, a study conducted among Canadian drug users and dealers showed that while slightly more than $40 \%$ of Darknet users are shopping on both online and offline platforms (open and closed markets), almost $50 \%$ of online users conduct their purchases entirely on online platforms (Weber \& Kruisbergen, 2019).

Even though several operations were carried out against the Darknet by law enforcement agencies, the popularity of the Darknet continues to increase. According to statistics, Darknet sales tripled between 2016 and 2017 (United Nations Office on Drugs and Crime, 2018). Other studies 
carried out among the drug users have shown that drug purchases through the Internet were slightly more than 9\% percent in 2018, which doubled the percentage of 2014 (United Nations Office on Drugs and Crime, 2018).

\section{Communication Methods}

Each buyer and dealer have their communication system to contact each other to continue their business in the drug market. Arrangements for the transactions could be carried out via telephone, in person, or the Internet. While some dealers ask for a prearranged date and time for delivery to provide safety for the shipment, others use more complicated communication methods with their suppliers such as one-time calling and two times calling (Tzvetkova et al., 2016) or other encrypted communication programs such as WhatsApp, etc.

Getting contact with the dealers or customers through the telephone is one of the most common methods in the illegal drug market. Therefore, to conduct a transaction, there is no need to provide permanent exchange points (Bucerius, 2007; Tzvetkova et al., 2016). Nevertheless, depending on the agreement or known places between seller and customer, meeting points are still used for the transactions (Bucerius, 2007; Tzvetkova et al., 2016). On some occasions, dealers use public places for a short period to extend their customer profile when they face financial problems. New dealers or some dealers who reenter business after a while also use open markets even though it is against common practices and unwritten codes. As soon as they build their profile again, they pull out of the street (Bucerius, 2007).

Owing to the Tor browser, other Darknet tools, and cryptocurrencies, the identities of both vendors and buyers kept secret in illegal transactions. However, deliveries of the purchased substances, which are in small amounts, are often carried out through postal services to be picked up by the buyers (United Nations Office on Drugs and Crime, 2018), which increases the postal and package burden of the legitimate delivery systems at the European countries (Europol, 2017)

\section{Drug Purity (Steering the Drug, Diluting, Cutting Drug, Adulterating)}

The correlation between drug purity and prices is also one of the most important data to measure drug prevalence on the streets (Caulkins, 2007; Caulkins \& Reuter, 1998). Purity and substitute substances used in the adulteration drugs affect behavioral changes among drug users in some regions (Eligh, 2020).

The purity of drugs is a controversial issue between the dealers and buyers. The main reason for adulterating drugs is to increase profit from the drug business. Adulteration is one of the standard practices of dealers, especially those who operate in the drug market (Broséus et al., 2016; Cole et al., 2011; Tzvetkova et al., 2016). Nevertheless, most street dealers are reluctant to adulterate the drugs because they would like to maintain their reputations even when the drug shortages are felt (Coomber, 1997; Coomber \& Maher, 2006; Tzvetkova et al., 2016).

Previous studies have shown that the purity of smuggled drugs in bulk quantities is higher than those drugs on the streets (Broséus et al., 2016; Coomber, 1997; Coomber \& Maher, 2006). Therefore, the purity of the drug changes depends on where and what form the drug is. For example, when heroin first imported, it is generally $80-90 \%$ pure; however, its purity is reduced to $12 \%$ on the street level. The more drugs are distributed to the street level, the less purity they have (Coomber, 1997; Coomber \& Maher, 2006).

The adulteration of the products mostly occurs among the high-level distributors rather than among street-level drug traffickers (Coomber, 1997; Tzvetkova et al., 2016). The adulteration of drugs such as heroin and cocaine requires a certain level of knowledge because of health and quality 
issues (Tzvetkova et al., 2016). Because of a lack of equipment and technical information, smaller dealers or those already at the bottom of the dealing chain are less likely to be involved in the adulteration process (Coomber, 1997). They can mix low-quality materials with high-quality drugs, but they should warn their customers (Tzvetkova et al., 2016). Avoiding selling low-quality products became one of the most critical issues even among high-level drug traffickers like highlevel American cocaine traffickers because dealers can ask for replacement or reject low-quality cocaine shipments (Fuentes, 1999; Tzvetkova et al., 2016), which might be related to profit expectations rather than a commitment to their customers. Drug dealers prefer to cheat on their customers by stealing from the promised amount or increasing the drug prices (Coomber \& Maher, 2006; Tzvetkova et al., 2016).

\section{The Purity Level of the Drugs}

Based on the information provided by European drug checking services, the purity of cannabis is somewhere between 13 to $24 \%$ in resin form, $9-12 \%$ in herb form. In comparison, the purity of cocaine is somewhere between 23\% and 87\% (European Monitoring Centre for Drugs and Drug Addiction, 2020). Nevertheless, studies have shown that most users do not test drugs either before or after they bought them (Coomber \& Maher, 2006; Decorte, 2001). Only 4\% of users use pharmacological methods to test cocaine, while the rest continue their transactions with dealers with whom they have already had experience (Coomber \& Maher, 2006).

Except for the shortage period between 2009-2011, heroin purity has been stabilized somewhere between 18-30\% in the European drug market (European Monitoring Centre for Drugs and Drug Addiction, 2020). Even when dissatisfied with the product, customers return to dealers, a situation mostly observed among the heroin users (Coomber \& Maher, 2006).

The purity level of synthetic drugs varies. According to European drug checking services results, amphetamine purity somewhere between $9 \%$ and $34 \%$, while methamphetamine is between 26-81\% across Europe. However, reportedly the purity of amphetamine has consistently increased in the last ten years (European Monitoring Centre for Drugs and Drug Addiction, 2020).

\section{Drug Prices}

Like legitimized commercial businesses, drug prices change based on the quality of drugs and where they are sold in the drug markets. For example, amphetamine prices are somewhere between 10-24 Euros while methamphetamine prices are somewhere between 17-64 Euros (European Monitoring Centre for Drugs and Drug Addiction, 2020), and ecstasy prices are estimated somewhere between 4-16 Euros. Nevertheless, a recent report showed that ecstasy prices have decreased while the purity has increased in the last ten years (European Monitoring Centre for Drugs and Drug Addiction, 2020).

Finally, cannabis prices are 9-14 Euros if sold in resin form and 7-12 Euros if sold in herb form (European Monitoring Centre for Drugs and Drug Addiction, 2020).

\section{Violence and/or Cooperation Among the Street-Level Drug Traffickers in NRW}

Violence is one of the most prevalent characteristics of organized crime groups to protect their turfs from other organized crime groups (Europol, 2017) and retrieve stolen drugs, revenge for betrayal, and solve payment issues (Bucerius, 2007; Coomber \& Maher, 2006; Tzvetkova et al., 2016). Open drug markets are more open to violence than the closed market because the dealers 
in a closed market have more intimate relations with their customers; even so, depending on the situation, spontaneous violence or conflicts can be seen among the parties (Bucerius, 2007).

Conflicts and violence among drug trafficking organizations are less concerning than the fear of being caught and noticed by the police (Tzvetkova et al., 2016). Contrary to general belief, there are few conflicts among the street-level drug dealers. They cooperate and support each other rather than fighting each other (Coomber \& Maher, 2006; Tzvetkova et al., 2016). There is solidarity among the street dealers one way or another. For example, while deciding the street level price of illegal drugs, they consult each other. This cooperation between the drug dealers goes beyond just the asking price to the lending drugs to each other, transportation of drugs, and information exchange regarding police activity. Therefore, most drug transactions and negotiations among the dealers were carried out peacefully. Furthermore, they do not want to draw the attention of law enforcement agencies in those territories where they operate (Coomber \& Maher, 2006).

\section{Methodology}

\section{Research Design}

This study uses a qualitative research method, which was as an analysis of narrative inquiry. This qualitative research method is interested in revealing the meaning of a phenomenon and uncovering specific behavioral changes rather than searching cause and effect relation (Merriam \& Tisdell, 2016; Piquero \& Weisburd, 2009). Narrative inquiry analysis includes experiences of the subjects, which were expressed in their lives and stories (Merriam \& Tisdell, 2016). Given the nature of research questions, this study includes interviews with the participants who either used or sold various drugs before and during the COVID-19 pandemic to understand if there are any behavioral changes in drug markets and price fluctuation during the COVID-19 and before the Corona-19 pandemic. Therefore, the study focuses on those who purchase and sell illegal drugs from the open, closed markets, and the Internet.

\section{Participants and Sampling}

The participants of this study were selected by using a snowball sampling method. A snowball sample is one of the most common methods to collect data as a purposeful sampling method to locate several key participants who met a study's criteria. After finding the right participant and/or participants, a researcher reaches other participants based on the key participant's information and reference (Merriam \& Tisdell, 2016). In this particular study, the first participant was met in March 2020, in Cologne, North Rhine-Westphalia, when the pandemic burst out, to collect data to analyze illegal drug market changes and drug price fluctuations in the illegal drug market. Nevertheless, some participants were selected in Essen city. During the pandemic, the researcher used participants' previous references and interactions in the social environment.

Participants of this study were mostly selected among the various market beneficiaries and multiple time illegal drug users. Nevertheless, most participants were cannabis users, and only a couple of them have already operated as street-level drug distributors. Therefore, the price measurement of the drugs was at the street level rather than at the wholesale level.

A total of 13 subjects were used in this study. The age of the participants ranged from 24 to 37 (Median = 30.07). Only three participants do not have German citizenship, while the rest of the participants have. Nevertheless, some were from various cultural and ethnic backgrounds. They were either born and raised by German families or children of the second generation of immigrated 
families or children of mixed families with either the father or the mother being a German citizen. All participants were assigned a number as a pseudonym. See Table 1 below.

Participants, some of whom were multiple drug users, used six different types of drugs including, cannabis, captagon, cocaine, ecstasy, ketamine, spice-bonzai.

Table 1

Demographics, Type of Substance Used, Prices, Distribution Methods

\begin{tabular}{|c|c|c|c|c|c|c|c|}
\hline Participant & Gender & Age & $\begin{array}{c}\text { Substance } \\
\text { Type }\end{array}$ & $\begin{array}{c}\text { All-Time } \\
\text { Market Type }\end{array}$ & Price & $\begin{array}{c}\text { All-Time } \\
\text { Communication } \\
\text { Method }\end{array}$ & $\begin{array}{c}\text { All-Time } \\
\text { Distribution } \\
\text { Method }\end{array}$ \\
\hline Participant 1 & Male & 24 & $\begin{array}{c}\text { Cannabis } \\
\text { SPICE- } \\
\text { Bonzai } \\
\text { Captagon }\end{array}$ & $\begin{array}{c}\text { Open Market } \\
\text { Closed Market }\end{array}$ & $\begin{array}{l}10 \text { Euro } \\
10 \text { Euros } \\
10 \text { Euros }\end{array}$ & $\begin{array}{c}\text { Telephone } \\
\text { Face to Face }\end{array}$ & Pick up \\
\hline Participant 2 & Male & 28 & $\begin{array}{c}\text { Captagon } \\
\text { Cocaine } \\
\text { Cannabis }\end{array}$ & $\begin{array}{c}\text { Closed Market } \\
\text { Open Market } \\
\text { Internet }\end{array}$ & $\begin{array}{l}4 \text { Euros } \\
10 \text { Euros } \\
45 \text { Euros }\end{array}$ & $\begin{array}{c}\text { Telephone } \\
\text { Face to Face } \\
\text { Internet }\end{array}$ & $\begin{array}{l}\text { Drop Off } \\
\text { Pick up } \\
\text { Postal }\end{array}$ \\
\hline Participant 3 & Male & 30 & Captagon & Internet & 3 Euros & Internet & Postal \\
\hline Participant 4 & Male & 27 & Ecstasy & Internet & 5 Euros & Internet & Postal \\
\hline Participant 5 & Male & 32 & Cannabis & $\begin{array}{c}\text { Closed Market } \\
\text { Open Market }\end{array}$ & 10 Euros & Telephone & $\begin{array}{l}\text { Pick up } \\
\text { Drop Off }\end{array}$ \\
\hline Participant 6 & Male & 26 & $\begin{array}{c}\text { Cannabis } \\
\text { Cocaine } \\
\text { Ecstasy }\end{array}$ & Closed Market & $\begin{array}{l}10 \text { Euros } \\
80 \text { Euros } \\
5 \text { Euros }\end{array}$ & $\begin{array}{c}\text { Telephone } \\
\text { Face to Face }\end{array}$ & $\begin{array}{l}\text { Pick up } \\
\text { Drop Off }\end{array}$ \\
\hline Participant 7 & Male & 31 & Cannabis & Closed Market & 10 Euros & $\begin{array}{c}\text { Telephone } \\
\text { Face to Face }\end{array}$ & $\begin{array}{l}\text { Pick up } \\
\text { Drop Off }\end{array}$ \\
\hline Participant 8 & Male & 37 & $\begin{array}{c}\text { Cannabis } \\
\text { Cocaine }\end{array}$ & Closed Market & $\begin{array}{l}10 \text { Euros } \\
55 \text { Euros }\end{array}$ & $\begin{array}{c}\text { Telephone } \\
\text { Face to Face }\end{array}$ & Pick up \\
\hline Participant 9 & Male & 28 & $\begin{array}{l}\text { Ecstasy } \\
\text { Cocaine }\end{array}$ & Closed Market & $\begin{array}{l}5 \text { Euros } \\
70 \text { Euros }\end{array}$ & $\begin{array}{c}\text { Telephone } \\
\text { Face to Face }\end{array}$ & $\begin{array}{l}\text { Pick up } \\
\text { Drop Off }\end{array}$ \\
\hline Participant 10 & Male & 33 & $\begin{array}{c}\text { Cannabis } \\
\text { Ecstasy } \\
\text { Cocaine }\end{array}$ & Closed Market & $\begin{array}{l}10 \text { Euros } \\
7 \text { Euros } \\
70 \text { Euros }\end{array}$ & Telephone & Pick up \\
\hline Participant 11 & Male & 30 & Ecstasy & Internet & 4 Euros & Internet & Postal \\
\hline Participant 12 & Male & 34 & $\begin{array}{l}\text { Cannabis } \\
\text { Ketamine }\end{array}$ & $\begin{array}{l}\text { Closed Market } \\
\text { Internet }\end{array}$ & $\begin{array}{l}10 \text { Euros } \\
40 \text { Euros }\end{array}$ & $\begin{array}{l}\text { Telephone } \\
\text { Internet }\end{array}$ & $\begin{array}{l}\text { Pick up } \\
\text { Drop Off }\end{array}$ \\
\hline Participant 13 & Male & 31 & $\begin{array}{c}\text { Cannabis } \\
\text { Ecstasy }\end{array}$ & Closed Market & $\begin{array}{l}10 \text { Euros } \\
7 \text { Euros }\end{array}$ & Telephone & Pick up \\
\hline
\end{tabular}

During their interaction with dealers or customers, they use various tools, such as the telephone, the Internet, or face-to-face communication. They receive their desired drugs in various ways, such as the postal service, dealer delivery, or pick up from the dealer. While the closed market was the most preferred market by the participants (10), the Internet was the second (5), and the open market was the least preferred (3) by the participants. Nevertheless, some participants 
used more than one market according to drug preference and time of consumption. For example, during clubbing, participants prefer open or closed markets rather than the Internet.

Cannabis was the most consumed drug. Nine participants consumed cannabis, following cocaine at five, captagon and ecstasy at three, and ketamine and bonzai-spice with only one participant each.

\section{Data Collection}

The study's data collection process started in March 2020, after the Corona-19 pandemic seriously began to affect German society with curfews and travel restrictions and ended in September 2020 while the Corona pandemic still was going on. Thirteen subjects were recruited during the interviews. Data collection was carried out in three steps: collecting the stories, taking notes based on observations during the social interaction in their environment, and analyzing collected data. As a nature of the business, participants were conducting their activities clandestinely; therefore, none of the participants desired their conversations recorded, but some gave their consent for their stories to be written in presence, and notes were taken after each interaction.

Because of the Corona precautions, meeting with new subjects and finding an appropriate environment to interact then later conduct interviews was one of the most challenging parts of the data collection and communicating with them in their language. Some conversations were translated from German to English and some from German to Turkish, all of which were eventually translated into English. Due to the limited opportunities to introduce and meet new subjects, the snowballing sampling method was selected to collect data for this specific study.

After May and June 2020, COVID-19 precautions loosened, the researcher could meet some of the subjects either in their places and public places to carry out further interviews. After earning the participants' trust, the researcher was allowed to participate in their social activities on some occasions to observe their environment and relationships among them, which also provided an opportunity to access new subjects.

\section{Data Analysis}

A content analysis of the narrative stories was conducted and entailed by reviewing the interviews and field notes, reading the transcripts, and categorizing notes and themes. As the first step of content analysis, some of the interviews were translated into English; then, all of the interviews and field notes, which were collected during the data collection process, were coded and categorized to correspond to each research question. In order to meet the criteria of research questions, each transcript was analyzed line by line and compared to literature within the related themes.

Not all information gathered was used in this study, as the chats' scope went beyond the subject of this study, including their life stories, reasons for starting to use, and their life expectancies. An opportunity existed to witness their transactions and consumption. Therefore, the researcher had an opportunity to observe their interactions and behaviors alone or among themselves during COVID-19 was present. 


\section{Findings}

\section{Drug Market Type and Distribution Methods}

Even though in the literature drug market types are classified as open and closed markets, in the recent decade, the Internet, specifically Darknet, became another market for both drug sellers and buyers.

This study showed that the closed drug market was the most commonly used drug market among the alternatives. Ten participants used closed drug markets. Simultaneously, the Internet was the second most used market used by 5 participants, and the open market was the least used drug market preferred by only 3 participants. Only, four participants used multiple illegal drug markets in their transactions. However, during Corona, the participants of this study used a closed market for their illegal purchases. None of the participants bought illegal drugs from open market and internet. See Figure 1.

Figure 1

Preferred Market Type

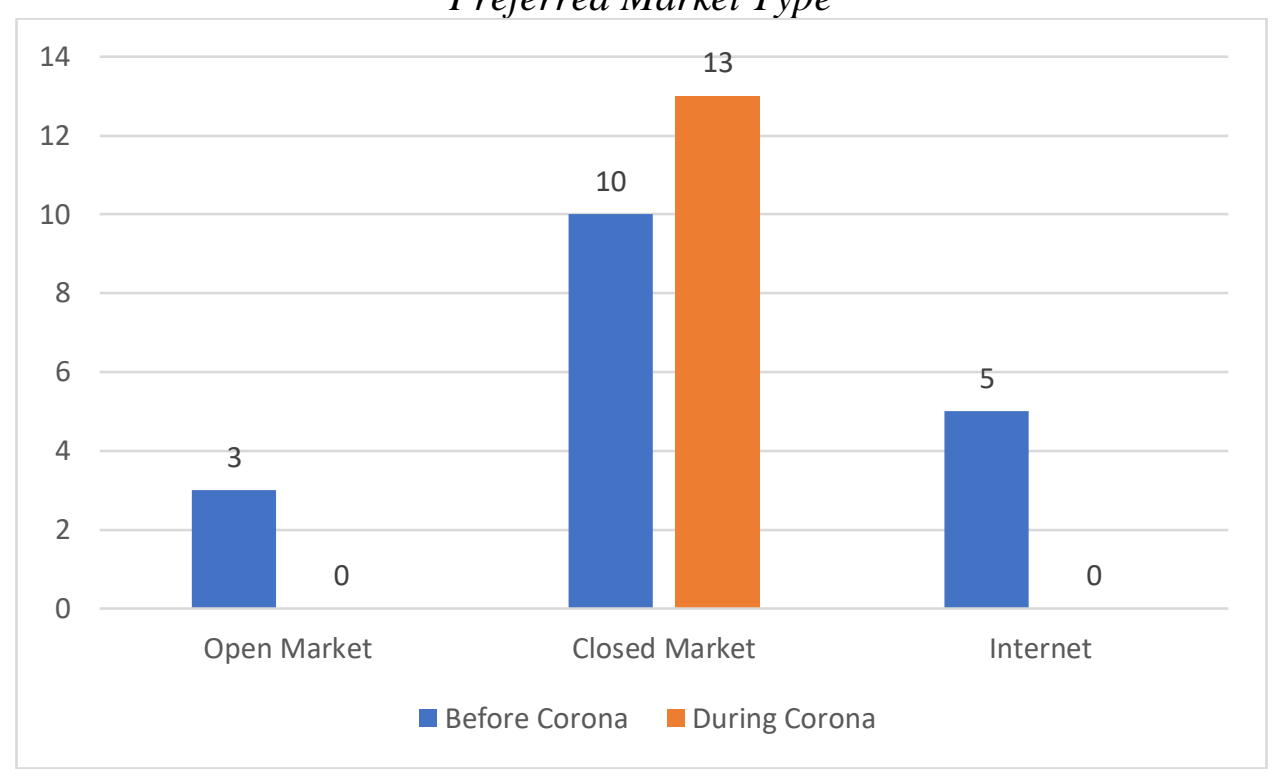

Before the COVID-19, open market dealers only operate on a particular turf to be visible to their customers or potential customers, and dealers were not carrying drugs on their body or belongings. They only contacted their customer in known locations and diverted their customers to another location to avoid curious eyes, especially from police intervention during a transaction. Then, the dealer brought the drug to their customer at the second arranged meeting point. A participant stated his experience

When I went to the train station, I told my dealer that I am looking for stuff. He asked me to wait at another spot, which was most likely one street further or backward. Then he disappeared from my sight. A few minutes later, he brought the dope. But the interesting thing is that he is never scared of being caught. He is also selling drugs to other people whom he doesn't know. Why should he scared? He is aware that since the substance 
is not on him, the risk is low. If caught by the police, he would probably tell that he was only a user (Participant 5).

During the curfew, open market sellers, located in public places such as the city centers and train stations in the suburbs, began to operate in closed markets since there is less opportunity to reach customers. Considering the main reason for operating in an open market is to reach more customers and/or find new customers, the street-level dealers cannot achieve these goals in times of curfews. As soon as the curfews were revoked, some dealers began to operate in the open market again.

Before the Corona, when I wanted to buy something, I went to the places where my dealer actively was. However, during Corona, because there wasn't anyone on the streets, and my dealers weren't on the streets. Like every other dealer, my dealers also began to deliver drugs to their customers. Delivery addresses are either their addresses or somewhere close to their addresses. During the curfew, I also got in contact with my dealer and asked for some drugs. He brought me to somewhere close to my address (Participant 2).

In comparing the drug market situation before and during the COVID-19 pandemic, participants said there were no market dynamics changes except for curfew times. Before and during the pandemic, there seems to have been no problem in providing illegal substances in the closed market. All participants who wanted to buy drugs from their dealers could contact them without any difficulty using either telephone or visiting their sellers in their prearranged selling points.

COVID-19 also did not affect the method of communication between dealers and their customers. Closed market dealers continued to communicate with their customers by phone. This communication method did not change during curfew and after curfew during the pandemic period. While most participants preferred to talk to their dealer on the phone, at least to make an arrangement, some participants stated that they sent a text message to their dealer through WhatsApp or any other smartphone application.

However, there seems to modification in the drug distribution methods. While before users were going to their dealers to buy drugs, in the situation after the COVID-19 restrictions, dealers adapted their distribution method and began to make delivery (drop off) to their customers. See Figure 2.

Yet, not all the customers want their seller to know their houses; therefore, some customers just gave another meeting point that is very close to their houses to meet their dealers. Nevertheless, users who communicate via telephone with their dealers set a place to meet to pick up the drug.

It seems that none of the users had a problem in finding their desired drugs during this period. The situation even surprised my participants. During the interviews, 13 of my participants indicated that they still trust their dealers in terms of having no problem in the distribution of their desired products. Their dealers began to deliver to their homes or some other addresses.

However, some dealers were selective regarding their delivery depending on the amount of drugs to be bought. One participant stated that when he asked for the small amount, the dealer was reluctant to deliver, so the participant increased the amount. 
Figure 2

Drug Distribution Method

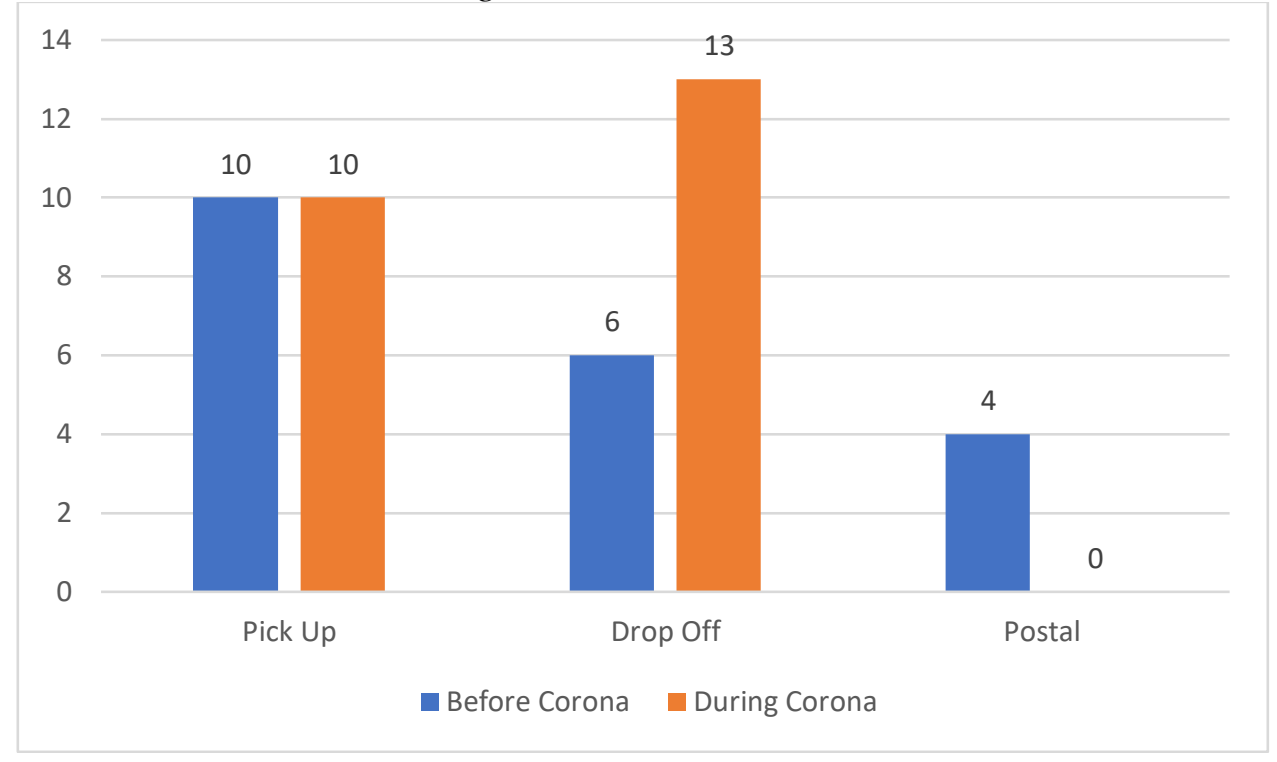

Drug sales from the Internet also became one of the preferred methods among drug users before the COVID-19 outburst. Five participants indicated that they bought drugs on the Internet. The delivery of drugs was carried out by postal cargo, mostly hidden in a book or under clothes like t-shirts.

Last year when I was a little short in cash, I ordered 2500 ecstasy pills from the Internet. It was a difficult time for me to provide enough support for my addiction. I both used and sold those pills to people around me. I am not going to lie; I made good money. But I never did again. At the time, I ordered from the Internet, and my package came among the clothes. I am surprised at how easy it was, and I paid money through bank transfer (Participant 1).

One participant also stated that buying drugs from the Internet was as easy as doing business with a dealer in person.

It is not complicated anymore for both users and dealers. Drugs can be bought from both the Darkweb and regular websites (Participant 11).

Participant 4 said

They don't need to hide. Some websites sell drugs from open websites. For example, https://www.partypack.de/ sells drugs without hiding themselves. Actually, you can find better offers on the Internet. Doing business is much better than buying regular dealers since websites give the exact purity level of the drugs (Participant 4). 
However, none of the participants indicated that they purchased from the Internet during the COVID-19. Even though they did not state any specific reason why they did not use the Internet for transactions, Participant 13 stated that

You know I am taking this sh...t for fun and having a good time with my friends and girlfriend. I am not an addict, occasional user, so I would like to use it when the environment is good, but ordering from the Internet...... really? I don't want to wait for momentary fun/enjoyment (Participant 13).

Therefore, some experimental users and recreational users prefer to provide drugs either from the open market or from their close friends for recreational use.

They often made payments using either cryptocurrency such as Bitcoin or electronic payments such as money transfer and PayPal. Crypto money seemed to be the most secure payment method for them. Participant 2 stated that

I made my payment by Bitcoin since I believe it is the most secure payment in buying drugs. But some of my friends are also making their payments with PayPal and money transfer. But I am afraid so since I have already been arrested several times with the accusation of possession of drugs (Participant 2).

During conversations with the participants about why there were not any shortages in the drug market, although there are strict restrictions, they told me that drugs that were coming from other countries in the past are now even produced in Germany.

In the past, dealers were bringing cannabis from Netherland; however, right now, it is already being grown in Germany. Pills are being produced here. Why would I be concerned (Participant 12)?

Synthetic drugs are produced in Europe, and in recent years, some cannabis laboratories are also found in Germany. Therefore, even though not all types of drugs, such as cocaine and heroin, most drugs are already being produced in Europe, which is the main reason why there is no shortage in the market.

\section{Drug Price and Purity}

Even though there are numerous types of drugs in the market, the participants of this study were mainly cannabis, ecstasy, captagon, and cocaine users. While some participants were polydrug users, others did want to change their drug habits because they did not like the after-effects of certain drugs.

The amount of drugs mainly remained limited to retail amounts, which was in most cases measured in grams or the number of pills. Some participants indicated that they were also involved in selling hundreds of tablets in the past to make some money and/or provide financial support for their consumption.

Drug prices vary based on the quality, where and from whom they are bought. For example, some participants paid 10 euros per pill for captagon, while others paid 3 or 4 euros. Participant 3 observed 
When I first bought captagon for the first time, I didn't know many dealers. The dealer whom I talked to give me the highest price since he saw me the first time. I continued to buy from him. After several weeks, the price of the drug became more expensive than I expected since I was using it regularly. Then, I decided to buy from the Internet, which cost me 3 euros per pill. There were no quality differences between the two pills (Participant 3).

According to some participants, buying from the Internet was the best option to get a better price in buying drugs. Moreover, participants claimed that they could find better quality products from the Internet.

When comparing prices before and during the COVID-19, all participants emphasized numerous times that there was no price fluctuation in the drug market. One participant stated that

There were no differences in the drug prices before and during the pandemic since none of the dealers want to lose their customers. Because they know this is a temporary situation (Participant 7).

Apparently, no fluctuation existed in drug prices before and during the COVID-19 pandemic, even in the curfew times when dealers began to make delivery (drop off) to their customers' houses.

Some type of drug prices seems to be fixed for specific amounts. For example, all cannabis users said they were buying cannabis at 10 Euros per gram, no more or less, even though some type of drug prices varied based on where or from whom drugs are bought. See Figure 3.

Figure 3

Illegal Substance Price Range

Substance

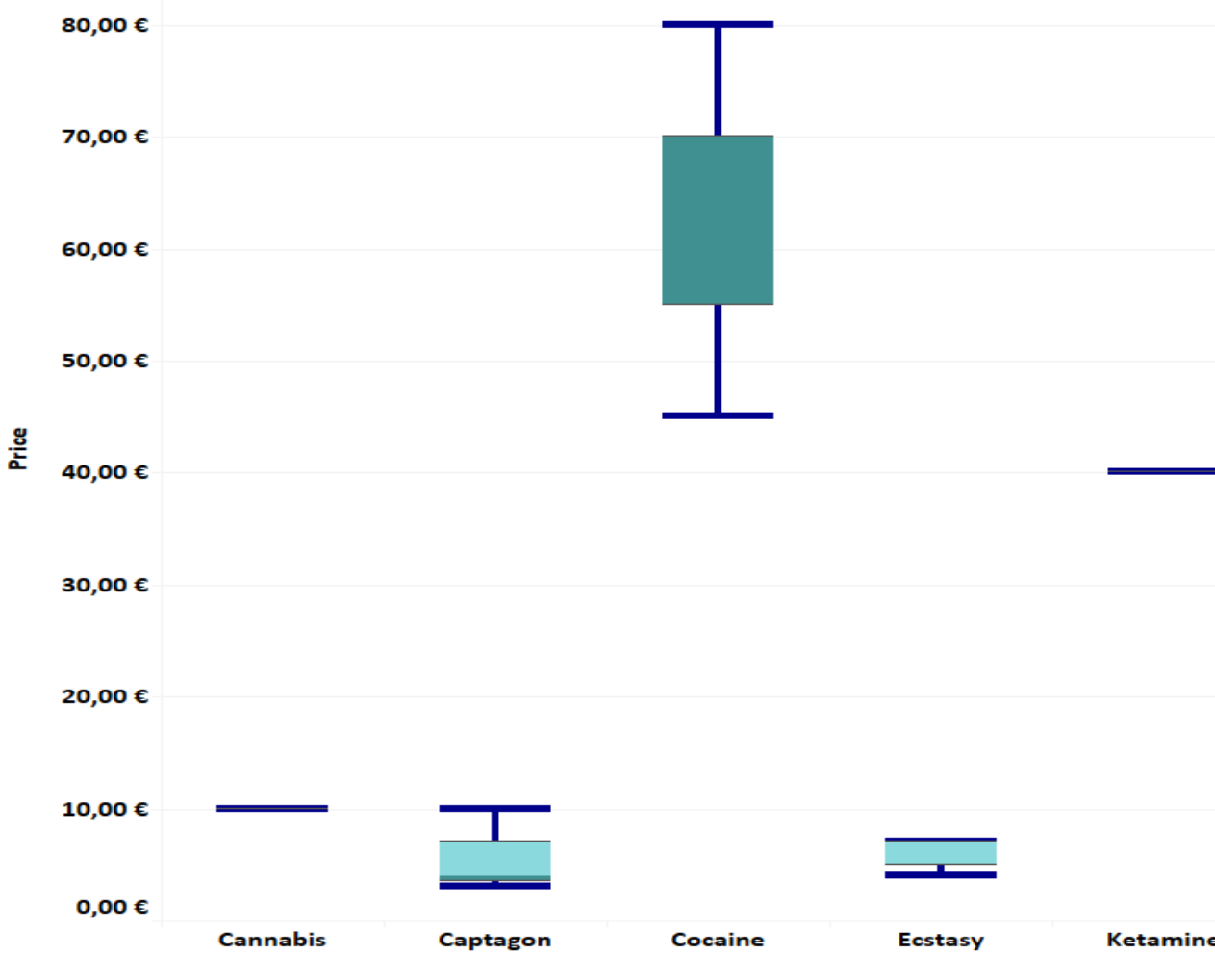


There seems to be no change in cocaine prices too. Data from the participants showed that cocaine prices were somewhere between 45-70 Euros according to the product's quality. Furthermore, because the price of cocaine is much higher than other drugs, only those who have regular jobs or high-income use cocaine.

There is also a price range in captagon and ecstasy. Captagon prices are somewhere between 3 and 10 Euros, and ecstasy prices are between 4 and 7 Euros, based on where they are bought. The Internet price seems to be the cheapest based on information provided by the participants. Only one participant used Ketamine, and only one participant used Spice-Bonzai, which were priced at 40 Euros and 10 Euros, respectively.

On the other hand, even though there was no change in quality in the drugs before and during the pandemic, according to the participants' statements, some dealers mispresented the amount for drugs like cannabis, shortchanging customers. Participant 5 stated that

The quality didn't change, but I think my dealer was ripping me off by giving less than promised. Of course, I didn't measure it since it was already a small amount, such as 100 grams of cannabis, but I felt it wasn't that much (Participant 5).

However, only one participant raised that concern, while others did not complain about being ripped off. Furthermore, it seems very difficult to reduce the amount contained in synthetic drugs because they are being sold in a pill version.

\section{Violence}

Violence is one of the characteristics of the drug markets. It is more prevalent among thighlevel traffickers than street-level dealers. None of the participants mentioned any type of violence among the dealers or between dealers or dealer and buyer. Reportedly, for almost five years (some of them have been using almost five years) of their experience, they never met with violence in the drug business.

This situation did not change during the COVID-19 pandemic. During seven months of research, no drug market-based violence was reported in the newspapers or heard from the participants. Participants stated that dealers know their territories, and they did not cross their boundaries. Moreover, most dealers were already working with established customers.

\section{Discussion}

Illegal drug use remains to be one of the biggest threats to society throughout the world. Approximately 275 million people, corresponding to $5.6 \%$ of the world's population between 15 64, who used at least one type of illegal drug, and almost half a million people lost their lives because of illegal drug consumption in 2015 (United Nations Office on Drugs and Crime, 2018). Cannabis and its derivates remain the most prevalent drugs globally, followed by cocaine, ATS, and opioids (United Nations Office on Drugs and Crime, 2018). According to EMCDDA 2019 Country Drug Report, more than $25 \%$ of the Germans used at least one of the illegal drugs in their lifetimes, slightly less than $10 \%$ who used illegal drugs in the last 12 months, and almost $5 \%$ who used illegal drugs in the last 30 days.

At the beginning of 2020, the COVID-19 pandemic crises burst out. Tens of millions have been infected with a serious disease, and more than 1.5 million people have lost their lives to date. To prevent the spread of disease, governments worldwide took serious precautions, including travel 
restrictions and curfews. Even though all these precautions decreased social life significantly, they also presented a perfect opportunity to prevent certain types of crimes such as smuggling and trafficking due to the travel restrictions and allowing law enforcement agencies to control streets, which help prevent criminal activities. As expected, law enforcement agencies seized more illegal drugs in this period than in the previous year.

Even though many drugs were seized due to the efforts of law enforcement agencies efforts, neither COVID-19 precautions, which were not explicitly taken to prevent illegal drug trafficking nor the pandemic itself had an effect on drug prices and distribution methods on the streets. The participants of this study stated that, except for the curfew times, open market dealers operated in the same regions or turfs where they used to sell drugs before the COVID-19. Furthermore, some open market dealers continued to operate in the closed markets.

There seemed to be no change in the closed markets. None of the participants had difficulty in finding their desired drugs despite successful seizures of law enforcement agencies and travel restrictions and curfews. Nevertheless, some behavioral changes were observed among the dealers in the street-level distribution of drugs. For example, while previously they were meeting their customer at certain spots, dealers began to deliver their products to their customers who did not want to go out during the pandemic. According to some researchers, drug distributors camouflage themselves as civilians who are doing sports or working; thus, they remained less visible (Eligh, 2020).

Both vendors and buyers still use a telephone to communicate with each other either by speaking on the phone or texting each other with smart app programs such as WhatsApp, as previously stated in research (Friis Søgaard et al., 2019). However, some studies have shown that in recent years recreational drug users changed their purchasing method by using the Internet, especially the Darknet, to provide anonymity, safety, and social distancing (Eligh, 2020). Thus, the Internet has become a trending marketplace for drug dealers and buyers, and drug distribution networks (Bertola, 2020). However, this study showed that none of the participants bought drugs from the Internet during the pandemic. Recreational users prefer to buy drugs without any delay from the closed markets. Furthermore, some dealers prefer to use non-smartphones because they believe it is more difficult to trace (Friis Søgaard et al., 2019).

Drug prices also didn't fluctuate during the Corona times compared to before Corona. European Monitoring Center for Drugs and Drug Addiction (2020) reported that ecstasy prices between 4-16 Euros, cannabis (herb form) prices between 9-20 Euros, cocaine prices between 38135 Euros. The result of this study also showed that cannabis price is almost fixed to 10 Euro in both Cologne and Essen, cocaine prices between 45-70 Euros, captagon prices between 3-10 Euros, ecstasy prices between 4-7 Euros, which are in the range of European Monitoring Center for Drugs and Drug Addiction 2020 report calculations. Apparently, there seemed to be no price change in the street prices even though one of the participants suspected a decreased amount of the drug than in a previous transaction.

Health issues are among the most critical factors that reduce drug consumption among recreational users rather than law enforcement efforts, as previously observed (Reuter, 1986). Considering both illegal drugs and the COVID-19 virus have a severe effect on the respiratory system, drug consumption might be assumed to decline under the current circumstances. However, according to this study's results, none of the consumers changed their drug use behavior and frequencies before or during the pandemic.

It was expected that, at the beginning of the pandemic, some degree of decrease in drug purity or rip off cases such as giving less amount than intended purchase to be occurred. According to some reports, at the beginning of the curfews, drug dealers put some additional ingredients in their products to prevent supply shortages, which might reduce intoxication because of overdose 
possibility (Eligh, 2020). However, none of the participants in this study confirmed a purity decrease in their products.

Violence is one of the most prominent characteristics of organized crime groups to protect their turfs from other organized crime groups (Europol, 2017). Considering tightening marketing opportunities during the COVID-19, conflicts might have been expected among the street-level drug distributors. However, this study did not find any evidence of illegal drug sale-related violence before or during the pandemic.

It seems that drug trafficking organizations strengthened their structure and networks by dealing with external factors such as increased controls, curfews, strengthen border controls based on their previous experiences, and continued to operate flawlessly during the COVID-19 pandemic (Eligh, 2020).

\section{Policy Recommendations}

Studies have shown that strict border controls are among the most essential factors in the prevention of drug trafficking (Paoli, 2002). However, it cannot be the only solution because most drug market demands are met from the internal sources if drug traffickers cannot reach their outsources when shortages occur (Paoli, 2002). Therefore, law enforcement agencies should focus on local groups such as street-level dealers and focus on trafficking groups that traffic the bulk of illegal substances.

Every geography or location has its dynamics and specifications with which to deal. Therefore, counter-strategies should be developed based on the dynamics of the region after a detailed analysis. For example, surveys can be applied in the local communities so that it can be understood where are the hot spots for drug distribution. Dedicated telephone hotlines can be established to receive tips and intelligence from the civilians to determine why there is a drug market in that specific area (Haracopos \& Hough, 2005).

Even though this study could not find any support to emphasize Internet drug sales during the pandemic, the Internet drug market has enormous potential. It has a potential to be one of the most important platforms in the future. The biggest challenge of investigating the Internet drug market, specifically Darknet, is anonymity. Nevertheless, law enforcement agencies still have tactical advantages in combating Darknet illegal activities, especially detecting postal services, which is the main distribution tool of the Darknet vendors besides traditional investigation tools and technics (Weber \& Kruisbergen, 2019). Therefore, law enforcement agencies should develop better strategies rather than shutting down those websites because those virtual shops will be opened under different names on other platforms (Bertola, 2020; United Nations Office on Drugs and Crime, 2018). In fact, the Darknet's closure with the previous operations did not affect more than half of the Darknet users, and it is growing swiftly (United Nations Office on Drugs and Crime, 2018). Statistics also showed that the Darknet's drug market was approximately 44 million dollars between 2011 and 2015. However, it increased somewhere between 170 and 300 million Euros annually (United Nations Office on Drugs and Crime, 2018).

\section{Limitations of the Study}

The most challenging part of the study was gaining the trust of participants because of the business's clandestine nature. Therefore, despite the fact that the information shared by the participants during the interviews cross-checked with the notes taken during the observation, there might be some unrevealed information regarding their roles and activities. 
The second limitation was the language barrier. Even though English was mostly used during interviews or introductions to the participants, some were more comfortable speaking German. Thus, language became an issue in some cases.

The third limitation was that this study was limited to a specific region rather than a nationwide study. Therefore, generalizing across Germany and Europe might not be possible.

Lastly, the data collected in this study limited were limited to after the COVID-19 outburst. No data were before COVID-19 to compare price fluctuations and changes in distribution methods before and during the pandemic era. Therefore, the data used to compare were gathered from the literature, and assumptions and observations of the samples and literature.

\section{References}

Aliyyah, R. R., Rachmadtullah, R., Samsudin, A., Syaodih, E., Nurtanto, M., \& Tambunan, A. R. S. (2020). The perceptions of primary school teachers of online learning during the COVID19 pandemic period: A case study in Indonesia. Journal of Ethnic and Cultural Studies, 7(2), 90-109.

Bertola, F. (2020). Drug Trafficking on Darkmarkets: How Cryptomarkets are Changing Drug Global Trade and the Role of Organized Crime. American Journal of Qualitative Research, 4(2), 27-34. https://doi.org/10.29333/ajqr/8243

Broséus, J., Gentile, N., \& Esseiva, P. (2016). The Cutting of Cocaine and Heroin: A Critical Review. In Forensic Science International (Vol. 262, pp. 73-83). Elsevier Ireland Ltd. https://doi.org/10.1016/j.forsciint.2016.02.033

Bucerius, S. M. (2007). "What Else Should I Do?" Cultural Influences on the Drug Trade of Migrants in Germany. Journal of Drug Issues, 37(3), 673-697. https://doi.org/10.1177/002204260703700309

Bullinger, L. R., Carr, J. B., \& Packham, A. (2020). COVID-19 and Crime: Effects of Stay-atHome Orders on Domestic Violence.

Byrne, J. J., \& Martinez, C. (2012). Study Guide CAMS Certification Exam.

Campedelli, G. M., Aziani, A., \& Favarin, S. (2020). Exploring the Immediate Effects of COVID19 Containment Policies on Crime: an Empirical Analysis of the Short-Term Aftermath in Los Angeles. American Journal of Criminal Justice, 1-40. https://doi.org/10.1007/s 12103020-09578-6

Caulkins, J. P. (2007). Price And Purity Analysis For Illicit Drug: Data And Conceptual Issues. Drug and Alcohol Dependence, 90(SUPPL. 1), 1-28. https://doi.org/10.1016/j.drugalcdep.2006.08.014

Caulkins, J. P., \& Reuter, P. (1998). What Price Data Tell Us About Drug Markets. Journal of Drug Issues, 28(3), 593-612. https://doi.org/10.1177/002204269802800302

Cole, C., Jones, L., McVeigh, J., Kicman, A., Syed, Q., \& Bellis, M. (2011). Adulterants In Illicit Drugs: A Review Of Empirical Evidence. In Drug Testing and Analysis (Vol. 3, Issue 2, pp. 89-96). John Wiley \& Sons, Ltd. https://doi.org/10.1002/dta.220

Coomber, R. (1997). The Adulteration Of Drugs: What Dealers Do To Illicit Drugs, And What They Think Is Done To Them. Addiction Research and Theory, 5(4), 297-306. https://doi.org/10.3109/16066359709004344

Coomber, R., \& Maher, L. (2006). Street-Level Drug Market Activity in Sydney's Primary Heroin Markets: Organization, Adulteration Practices, Pricing, Marketing and Violence. Journal of Drug Issues, 36(3), 719-753. https://doi.org/10.1177/002204260603600310

Decorte, T. (2001). Quality Control by Cocaine Users: Underdeveloped Harm Reduction Strategies. 161-175. 
Demirbüken, H., Mili, H., Townsend, J., Rahmonberdiev, U., Kurbanov, O., Johansen, R., Kunnen, S., Kuttnig, K., \& Le Pichon, T. (2009). Addiction, Crime, and Insurgency: The transnational threat of Afghan opium. 1-143. https://www.unodc.org/documents/data-andanalysis/Afghanistan/Afghan_Opium_Trade_2009_web.pdf

Dobkin, C., \& Nicosia, N. (2009). The War On Drugs: Methamphetamine, Public Health, And Crime. American Economic Review, 99(1), 324-349. https://doi.org/10.1257/aer.99.1.324

Eligh, J. (2020). Crisis and Opportunity: Impacts of the coronavirus pandemic on illicit drug markets. May. www.globalinitiative.net

EMCDDA. (2019). Drug-Related Deaths And Mortality In Europe (Issue July). https://dataunodc.un.org/Drugs/Mortality/Europ

European Monitoring Centre for Drugs and Drug Addiction. (2020a). European Drug Report 2020:

Trends and developments. In Report. https://doi.org/10.2810/123451

European Monitoring Centre for Drugs and Drug Addiction. (2020b). European Drug Report Trends and Developments. In Trusts \& Trustees (Vol. 13, Issue 10). https://doi.org/10.2810/123451

European Monitoring Centre for Drugs and Drug Addiction and Europol. (2020). EU Drug Markets: Impact of COVID-19 (Issue May). https://doi.org/10.2810/19284

Europol. (2017). How Illegal Drugs Sustain Organised Crime in the EU. 15. https://www.europol.europa.eu/sites/default/files/documents/business_fundamentals_how _illegal_drugs_sustain_organised_crime_in_europe.pdf

Friis Søgaard, T., Kolind, T., Birk Haller, M., \& Hunt, G. (2019). Ring And Bring Drug Services: Delivery Dealing And The Social Life Of A Drug Phone. International Journal of Drug Policy, 69, 8-15. https://doi.org/10.1016/j.drugpo.2019.02.003

Fuentes, J. (1999). The life of a cell: managerial practice and strategy in colombian cocaine distribution in the united states. https://elibrary.ru/item.asp?id=5498033

Garbe, A., Ogurlu, U., Logan, N., \& Cook, P. (2020). Parents' Experiences with Remote Education during COVID-19 School Closures. American Journal of Qualitative Research, 4(3), 4565. https://doi.org/10.29333/ajqr/8471

Haracopos, A., \& Hough, M. (2005). Drug Dealing in Open-Air Markets. In Policing: An International Journal of Police Strategies \& Management (Issue 31).

May, T., \& Hough, M. (2004). Drug markets and distribution systems. Addiction Research and Theory, 12(6), 549-563. https://doi.org/10.1080/16066350412331323119

Merriam, B. M., \& Tisdell. (2015). Qualitative Research. http://library1.nida.ac.th/termpaper6/sd/2554/19755.pdf

Merriam, S., \& Tisdell, E. (2015). Qualitative Research: A guide to Design and Implementation. https://www.google.com/books?hl=en\&lr=\&id=JFN_BwAAQBAJ\&oi=fnd\&pg=PA137

$\& d q=$ Merriam,+S.+B.+(2009).+Qualitative+research:+A+guide+to+design+and+implem entation.+San+\%09Francisco,+CA:+Jossey+Bass.\&ots=wN-

XQO0C56\&sig=2Pzh10BzS9W71wkmJcD0N0Yk_6A

Mohler, G., Bertozzi, A. L., Carter, J., Short, M. B., Sledge, D., Tita, G. E., Uchida, C. D., \& Brantingham, P. J. (2020). Impact Of Social Distancing During Covid-19 Pandemic On Crime In Los Angeles And Indianapolis. Journal of Criminal Justice, 68, 101692. https://doi.org/10.1016/j.jcrimjus.2020.101692

Ojha, A. (2020). Is Pandemic a Class-Ridden? An Appraisal from New York Ci. Journal of Ethnic and Cultural Studies, 7(3), 129-141.

Paoli, L. (2002). The Price Of Freedom: Illegal Drug Markets And Policies In Post-Soviet Russia. Annals of the American Academy of Political and Social Science, 582(JULY), 167-180. https://doi.org/10.1177/0002716202058002012 
Piquero, A. R., \& Weisburd, D. (2009). Handbook of Quantitative Criminology. In Handbook of Quantitative Criminology.

Reuter, P, \& Caulkins, J. P. (2004). Illegal "Lemons": Price Dispersion In Cocaine And Heroin Markets. In Bulletin on Narcotics (Vol. 56, Issues 1-2, pp. 141-165).

Reuter, Peter. (1986). Risks and Prices: An Economic Analysis of Drug Enforcement. In Crime and Justice (Vol. 7, pp. 289-340). https://doi.org/10.1086/449116

Sacco, L. N. (2015). Drug Enforcement In The United States: History, Policy, And Trends. Federal Drug Enforcement: History, Policies, Trends, 1-36.

Sandberg, S. (2012). The Importance of Culture for Cannabis Markets. British Journal of Criminology, 52(6), 1133-1151. https://doi.org/10.1093/bjc/azs031

Sikhangezile, N., \& Modise, M. A. (2020). Social distancing, cultural and psychological effects on learners in a rural setting in Zimbabwe. Journal of Ethnic and Cultural Studies, 7(3), 200209.

Sullivan, J. P., da Cruz, J. de A., \& Bunker, R. J. (2020). Third Generation Gangs Strategic Note No. 22: Rio's Gangs Impose Curfews in Response to Coronavirus. Small Wars Journal, 22, 4-11. https://smallwarsjournal.com/jrnl/art/third-generation-gangs-strategic-note-no-22rios-gangs-impose-curfews-response-coronavirus

Tzvetkova, M., Pardal, M., Disley, E., Rena, A., Talic, S., \& Forberger, S. (2016). Strategies for a risky business: How drug dealers manage customers, suppliers and competitors in Italy, Slovenia and Germany. International Journal of Drug Policy, 31, 90-98. https://doi.org/10.1016/j.drugpo.2016.04.012

United Nations Office on Drugs and Crime. (2008). Illicit Drug Trends in Afghanistan (Issue April).

United Nations Office on Drugs and Crime. (2018). World Drug Report 2018 Global overview of drug demand and supply. In World Drug Report 2018.

Weber, J., \& Kruisbergen, E. W. (2019). Criminal Markets: The Dark Web, Money Laundering And Counterstrategies - An Overview Of The 10th Research Conference On Organized Crime. In Trends in Organized Crime (Vol. 22, Issue 3, pp. 346-356). Trends in Organized Crime. https://doi.org/10.1007/s12117-019-09365-8

Zuccato, E., Castiglioni, S., Tettamanti, M., Olandese, R., Bagnati, R., Melis, M., \& Fanelli, R. (2011). Changes In Illicit Drug Consumption Patterns In 2009 Detected By Wastewater Analysis. Drug and Alcohol Dependence, 118(2-3), 464-469. https://doi.org/10.1016/j.drugalcdep.2011.05.007

\section{Notes on Contributor}

Umit Namli received his M.A. degree from the University of Baltimore Criminology Department and a Ph.D. degree from Durham University Government and International Affairs. He focused on transnational organized crime, drug trafficking, money laundering, and financial crimes during his academic studies. He is currently an Alexander von Humboldt Foundation Research Fellow at the University of Tubingen, Criminology Institute.

Manuscript received September 24, 2020 Final revision received February 2, 2021

Accepted February 4, 2021 